\title{
Pengaruh Latihan Senam Aerobic Mixed Impact Terhadap Berat Badan Anggota Sanggar Senam Female Aerobic Centre Padang.
}

\author{
Jumslimides \\ ${ }^{1}$ Fakultas Ilmu Keolahragaan, Universitas Negeri Padang, Indonesia. \\ E-mail: jumslimides@gmail.com
}

\begin{abstract}
Abstrak
Penelitian ini bersifat eksperimental yaitu yaitu memberikan perlakuan terhadap Anggota Sanggar Female Aerobic Centre Padang. Karena penelitian ini tidak menggunakan kelompok kontrol, maka penelitian ini termasuk kedalam eksperimen semu.. Tujuan penelitian untuk mengetahui program latihan senam aerobic mixed impact yang tepat untuk Anggota Sanggar Senam Female Aerobic Centre Padang, untuk mengetahui perubahan berat badan Anggota Sanggar Senam Female Aerobic Centre Padang, untuk mengetahui pengaruh latihan senam aerobic mixed impact terhadap berat badan Anggota Sanggar Senam Female Aerobic Centre Padang.

Populasi dalam penelitian ini adalah Anggota Sanggar Senam Female Aerobic Centre Padang yang berjumlah 30 orang. Teknik pengambilan sample adalah total sampling. Karena jumlah populasi yang relative sedikit, maka semua populasi dijadikan sampel yaitu sebanyak 30 orang.

Data dianalisis dengan menggunakan tenik persentase. Hasil yang diperoleh dalam penelitian adalah sebagai berikut : uji $\mathrm{t}$ antara pengaruh Latihan Senam Aerobic Mixed Impact terhadap berat badan diperoleh thit 4.39 untuk ttab pada taraf signifikan $\alpha=0,05$ yaitu 2.04. Berarti dalam hal ini terdapat pengaruh yang berarti antara Latihan Senam Aerobic Mixed Impact terhadap berat badan anggota sanggar senam female aerobic centre padang.
\end{abstract}

Kata Kunci: Latihan Senam Aerobik, Aerobic Mixed Impact, Berat Badan, Senam Female

\begin{abstract}
This research is experimental, i.e., giving treatment to the Members of the Padang Female Aerobic Center Studio. Because this study did not use a control group, this study was included in a quasi-experimental study. The aim of the study was to find out the right mixed aerobic exercise program for Padang Aeronautics and Female Aerobic Gymnasium Members, to find out the weight changes in the Female Aerobic Gymnasium Members of Padang, to determine the effect of mixed impact aerobic exercise on the weight of the Female Aerobic Center Gymnastics Member of Padang.

The population in this study were 30 members of the Female Aerobic Center Gymnastics Center in Padang. The sampling technique is total sampling. Because the population is relatively small, all populations are sampled as many as 30 people.

Data were analyzed using percentage techniques. The results obtained in the study are as follows: $t$ test between the effects of Aerobic Mixed Impact Gymnastic Exercise on body weight
\end{abstract}




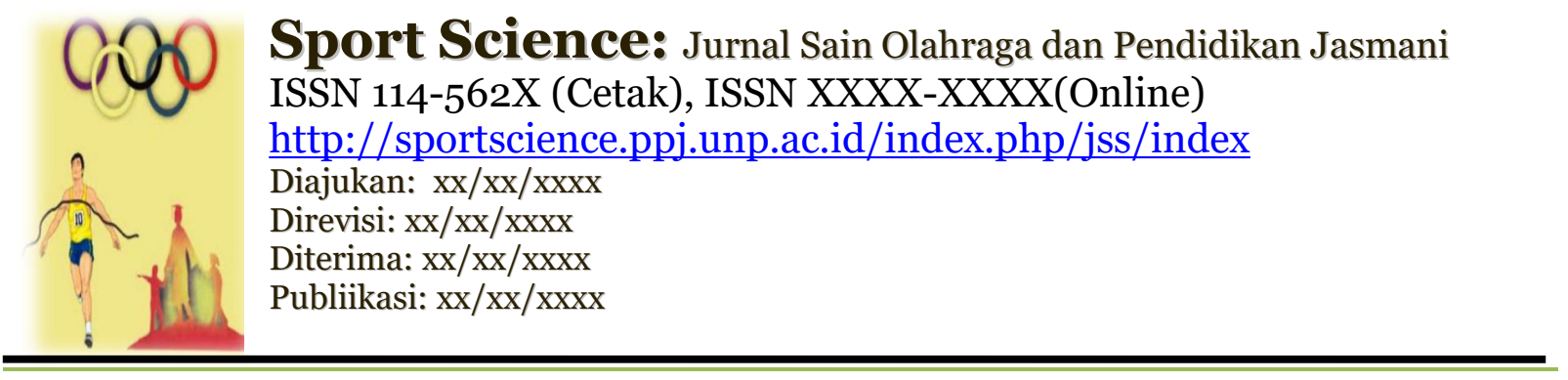

obtained thit 4.39 for ttab at a significant level $\alpha=0.05$ which is 2.04. Means in this case there is a significant influence between Aerobic Mixed Impact Gymnastic Exercise on the weight of female aerobics center gym members.

Keywords: Aerobics, Aerobic Mixed Impact, Body Weight, Female Gymnastics

\section{PENDAHULUAN}

Melakukan latihan olahraga yang teratur dan terukur, seseorang dapat memiliki berat badan yang ideal, serta dapat meningkatkan kesehatan dan kebugaran jasmani. Banyak olahraga yang dapat dilakukan salah satunya dengan senam aerobic. Senam aerobic adalah kegiatan latihan aerobic yang diberikan dalam bentuk gerakan-gerakan senam. Untuk menjalani aktifitas hidup sehari-hari kita memerlukan kondisi tubuh yang fit.

Pada umumnya masyarakat saat ini sudah memahami betapa pentingnya menjaga dan mempertahankan kesehatan serta kebugaran jasmani. Olahraga merupakan salah satu cara yang tepat dilakukan untuk memperoleh dan mempertahankan kebugaran tubuh. Asnaldi (2016) Olahraga yang dahulunya hanya bertujuan sebagai usaha peningkatan kualitas jasmani, telah berkembang menjadi multi tujuan, baik untuk kepentingan prestasi olahraga itu sendiri, ekonomi maupun politik.

Dewasa ini telah banyak berdiri sanggar-sanggar senam dan fitness serta club kebugaran. Berdasarkan observasi penulis pada Sanggar Senam Female AerobicCentre Padang, pengelola sanggar mengatakan bahwa anggota yang mengikuti latihan senam aerobic mixed impact sebagian besar ingin menurunkan berat badan, dan selebihnya ingin menghilangkan perasaan jenuh dari rutinitas sehari-hari, serta menambah pergaulan.

Namun permasalahannya masih banyak anggota yang mengikuti latihan senam aerobic mixed impact belum mengetahui akibat dari hasil latihan senam aerobic mixed impact tersebut. Hal di atas diduga karena jenis latihan yang belum sesuai dengan tujuan yang ingin dicapai, program latihan yang belum mengacu pada latihan aerobic, diet yang tidak terkontrol, mengabaikan pentingnya pemeriksaan kesehatan. Terhadap permasalahan di atas mungkin juga dipengaruhi oleh beberapa faktor, seperti: keturunan, umur, tinggi dan berat badan, volume latihan, serta kurangnya motivasi latihan.

Berdasarkan permasalahan dan faktor yang ikut memperngaruhi, penulis tertarik untuk melakukan penelitian pada anggota yang melakukan latihan senam aerobic mixed impact.Latihan memiliki makna tersendiri seperti yang dikemukan oleh beberapa ahli berikut ini:Menurut (Rothing dalam Syafrudin, 2005: 16), bahwa:

"Latihan adalah menggambarkan suatu proses pengerjaan/pengelolaan materi latihan seperti keterampilan-keterampilan gerakan dalam bentuk pelaksanaan yang berulang-ulang dan melalui tuntunan yang bervariasi. Selain itu latihan menunjukkan pelaksanaan yang berulangulang yang terautomatisasi melalui tuntunan-tuntunan yang lebih dipersulit guna memperbaiki kemampuan fisik".

Jadi, senam dilakukan untuk meningkatkan kemampuan gerak tubuh dengan tingkat kesulitan yang dipilih secara sengaja. Senam aerobic adalah latihan yang dilakukan untuk membakar lemak sambil memperbaiki kekencangan otot yang dipimpin oleh instruktur yang berpenglaman secara bersama-sama dan diiringi musik yang sesuai dengan irama/gerakan untuk anggota tubuh yang bergerak. Secara garis besar senam aerobic dapat dibedakan atas dua bagian, yaitu:

1) Senam Aerobic Tanpa Alat

a) Low Impact Aerobic (Aerobic Benturan Ringan)

Menurut Pinawati (2004: 11), "Gerakan-gerakan senam aerobic low impact banyak melangkah dengan satu kaki tetap dilantai, dan tidak melompat. Senam aerobic low impact, banyak diterapkan untuk latihan bagi pemula dan usia lanjut". Senam low impact dikenal dengan latihan yang aman dari resiko cedera. 
Sport Science: Jurnal Sain Olahraga dan Pendidikan Jasmani

ISSN 114-562X (Cetak), ISSN XXXX-XXXX(Online)

http://sportscience.ppj.unp.ac.id/index.php/jss/index

Hal ini juga dipertegas oleh Sumosardjono (1996: 62) "Bahwa dalam melakukan senam aerobic low impact, tidak ada lompatan, salah satu kaki selalu ada dilantai. Low impact aerobic dianjurkan bagi yang berat badannya berlebih, atau bagi mereka yang baru mulai melakukan latihan senam aerobic." Hal ini disebabkan oleh senam aerobic low impact tidak memberikan beban terlalu besar pada persendian.

b) High Impact Aerobic (Aerobic Benturan Keras)

Sumosardjono (1996: 62) menjelaskan bahwa gerakan-gerakan pada senam aerobic high impact mempunyai variasi gerak yang lebih menyenangkan sehingga tidak mudah menimbulkan kebosanan. Tetapi senam aerobic high impact tidak dianjurkan untuk orang yang mempunyai masalah pada persendiannya, dan juga pada orang pernah mengalami cedera pada tulang dan ototnya.

Pitnawati (2004: 11) juga mengemukakan, "Senam aerobic high impact membutuhkan daya tahan tubuh (stamina) yang berat karena senam ini gerakannya terdapat banyak lompatan/loncatan. Senam aerobic high impact efektif bagi orangorang yang ingin mengurangi berat badannya".

c) Mixed ImpactAerobic (Gabungan Dari Senam Aerobic Benturan Tinggi dan Ringan) Senam aerobic mixed impact menurut Jonni (2003: 6) merupakan latihan gabungan dari dua jenis senam yaitu senam aerobic low impact dan senam aerobic high impact. Bila kita mengangkat lutut harus betul-betul terangkat, jika tidak dapat menggunakan gerakan lompatan/loncatan. Sumosardjono (1996:63) mengatakan salah satu keuntungan melakukan senam aerobic mixed impact adalah tidak mudah menyebabkan kebosanan karena gerakannya yang bervariasi.

2) Senam Aerobic Pakai Alat

Jonni (2003: 9) mengklasifikasikan senam aerobic pakai alat, yaitu terdiri dari: "Aerobic dumble (senam aerobic pakai alat dumbel), aerobic stick (senam aerobic pakai alat tongkat), aerobicscart (senam aerobic pakai alat handuk), aerobicdingklick (senam aerobic pakai alat dingklik), stepaerobic/step rebok/rebok core training/streng rebok".

Jadi, dalam melakukan senam aerobic dapat menggunakan alat-alat bantu seperti dumble, tongkat, dingklik, bola, dan handuk.Latihan senam aerobic mixed impact merupakan senam gabungan dari senam aerobic low impact dan senam aerobic high impact yang dilakukan untuk membakar lemak tubuh dengan efek terhadap berat badan, dan untuk meningkatkan kebugaran jasmani, didalam melakukan gerakannya lutut harus betul-betul terangkat, jika tidak dapat menggunakan momentum lompatan, diiringi oleh musik, dipimpin oleh instruktur yang berpengalaman, serta lamanya latihan adalah 15-60 menit.Dengan melakukan latihan senam aerobic mixed impact yang terprogram dan kontiniu akan memberikan pengaruh terhadap berat badan. Sehingga seseorang bisa mendapatkan berat badan yang ideal.

\section{METODE}

Penelitian ini dilakukan dalam bentuk eksperimental, yaitu memberikan perlakuan terhadap Anggota Sanggar Female Aerobic Centre Padang. Karena penelitian ini tidak menggunakan kelompok kontrol, maka penelitian ini termasuk kedalam eksperimen semu.Penelitian ini akan dilaksanakan pada bulan Desember 2017 sampai dengan Januari 2017 di Sanggar Senam Female Aerobic Centre Padang. Populasi adalah keseluruhan subjek penelitian (Arikunto, 1998:115). Berdasarkan hal tersebut di atas, yang menjadi populasi dalam penelitian ini adalah Anggota Sanggar Senam Female Aerobic Centre Padang yang berjumlah 34 orang dan seluruhnya perempuan.

Teknik pengambilan sampel dalam penelitian ini adalah purposive sampling karena mempunyai pertimbangan-pertimbangan antara lain: umur diatas 35 tahun, sedang sakit, mengikuti senam kurang dari satu bulan. Jadi, yang menjadi sampel dalam penelitian ini berjumlah 30 orang. 


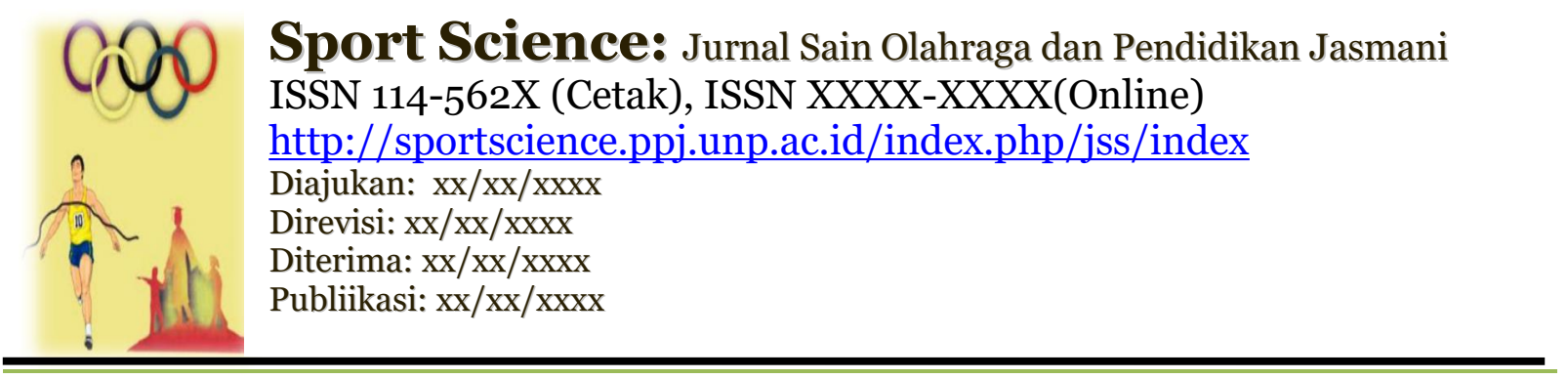

Untuk mendapatkan data dalam penelitian ini, dilakukan dua kali tes yaitu tes awal (pre tes), sebelum Anggota Sanggar Senam Female Aerobic Centre Padang melakukan latihan senam aerobic mixed impact dan tes akhir (post tes), setelah Anggota Sanggar Senam Female Aerobic Centre Padang melakukan latihan senam aerobic mixed impact 20kali pertemuan dengan frekuensi latihan 4 kali seminggu.

\section{Instrumen Penelitian}

Memperoleh data berat badan adalah dengan menggunakan timbangan. Sedangkan untuk mengukur tinggi badan adalah dengan mictrotoise. Sebelum melakukan tes yang harus disiapkan antara lain sebagai berikut:

\section{a. Alat-alat yang diperlukan untuk mengambil data:}
1) Blangko pengukuran tes awal
2) Blangko pengukuran tes akhir
3) Timbangan badan dalam satuan kilogram
4) Microtoice dalam satuan centimeter
5) Alat tulis

b. Petugas pelaksana tes: dan berat badan.

Dalam pelaksanaan tes, dilakukan oleh dua orang yaitu untuk pengukuran tinggi badan

\section{c. Pelaksanaan:}

Tes awal dilakukan sebelum Anggota Sanggar Senam FemaleAerobic Centre Padang melakukan latihan senam aerobic mixed impact, sedangkan tes akhir dilakukan sesudah Anggota Sanggar Senam FemaleAerobic Centre Padang mendapatkan perlakuan senam aerobic mixed impact sebanyak 20 kali pertemuan. Untuk lebih jelasnya dapat dilihat tabel sebagai berikut:

Tabel II. Jadwal Latihan Senam Aerobic Mixed Impact Sanggar Senam Female Aerobic Centre Padang

\begin{tabular}{|c|c|c|c|l|}
\hline No & Hari & Waktu & $\begin{array}{c}\text { Lama } \\
\text { Latihan }\end{array}$ & \multicolumn{1}{|c|}{ Keterangan } \\
\hline 1 & Senin & $17.00-18.00 \mathrm{WIB}$ & 55 menit & \multicolumn{1}{|c|}{15 menit pemanasan } \\
\hline 2 & Rabu & $17.00-18.00 \mathrm{WIB}$ & 55 menit & 20 menit inti 1 \\
\hline 3 & Jumat & $17.00-18.00 \mathrm{WIB}$ & 55 menit & 15 menit inti 2 \\
\hline 4 & Sabtu & $17.00-18.00 \mathrm{WIB}$ & 55 menit & 5 menit pendinginan \\
\hline
\end{tabular}

a. Pengukuran Berat Badan

Diketahui dengan pengukuran menggunakan alat timbangan badan yang telah ditera terlebih dahulu. Melakukan pengukuran berat badan, sampel berdiri tegak di atas timbangan dengan memakai baju seminim mungkin tanpa memakai alas kaki. Pada alat timbangan tersebut terdapat angka-angka dengan satuan kilogram yang ditunjukkan oleh jarum. Setelah jarum berhenti menunjukkan angka tertinggi maka itu merupakan berat badan seseorang dan dicatat (Surya Brata dalam Indah, 2006: 29).

b. Pengukuran Tinggi Badan

Diketahui dengan pengukuran menggunakan alat microtoise. Melakukan pengukuran tinggi badan, sampel berdiri tegak menghadap lurus ke depan, posisi kepala tegak, mata horizontal dengan telinga. Bahu tegak tidak ditarik ke belakang. Kepala, bahu, siku, pinggul, dan tumit menempel pada dinding (Pusat Pengkajian dan Pengembangan IPTEK Olahraga: 39). 


\section{Teknik Analisis Data}

Teknik analisis data yang digunakan untuk pengujian hipotesis dalam penelitian ini adalah menggunakan rumus t-tes yang berhubungan dengan taraf signifikan $5 \%$ dengan rumus:

$$
t=\frac{\left(\bar{X}_{1}-\overline{X_{2}}\right)}{\sqrt{\frac{\sum D^{2}-\frac{\left(\sum D\right)^{2}}{N}}{N(N-1)}}}
$$

Keterangan:

$$
\begin{array}{lll}
X_{1} & = & \text { meansampel ke } 1 \\
X_{2} & = & \text { mean sampel ke } 2 \\
\mathrm{D} & = & \text { beda antara skor sampel } 1 \text { dan } 2 \\
\mathrm{D}^{2} & = & \text { beda pangkat dua } \\
\sum \mathrm{D} & = & \text { jumlah semua beda } \\
\sum \mathrm{D}^{2} & = & \text { jumlah semua beda yang telah dipangkat } \\
\mathrm{N} & = & \text { jumlah pasangan }
\end{array}
$$

Derajat kebebasan: $\mathrm{dk} / \mathrm{df}=\mathrm{N}-1$

(Sudjana, 1992: 244)

\section{HASIL DAN PEMBAHASAN \\ Hasil Penelitian}

Data yang telah dikumpulkan dalam penelitian ini, sebelum diolah terlebih dahulu diverifikasi (seleksi). Hal ini dilakukan untuk melihat data yang memenuhi syarat yang akan diolah. Dengan adanya pengawasan, bimbingan dan pengontrolan yang cukup ketat terhadap Latihan Mixed Impact Aerobic. Data yang berasal dari kelompok test awal dan tes akhir (pree dan posttest) dapat diolah. Analisis data dalam penelitian ini dimaksud untuk melihat karakteristik sebelum dan sesudah di lakukannya Latihan Mixed Impact Aerobic. Untuk lebih jelasnya dapat dilihat sebagai berikut:

Tabel III.

Rerata hitung, standar deviasi, nilai minimum dan Nilai maksimum, tes wal dan tes akhir

\begin{tabular}{|c|c|c|c|c|}
\hline No. & Kelompok & Statistik & Tes Awal & Tes Akhir \\
\hline \multirow{4}{*}{1} & & Mean & 57.33 & 55.78 \\
& Latihan Mixed & Std. Dev & 7.86 & 7.37 \\
& Impact Aerobic & Min & 42.00 & 43.00 \\
& & Max & 75.00 & 73.00 \\
\hline
\end{tabular}

Berpedoman dari tabel di atas, nilai kedua kelompok Latihan Mixed Impact Aerobic untuk tes awal didapat nilai mean 57.00, standar deviasi 7.86, nilai minimum 42.00, dan maksimum 75.00 dan untuk tes akhir untuk Latihan Mixed Impact Aerobic didapat mean 55.78, standar deviasi 7.37, nilai minimum 43.00, dan maksimum 73.00 .

Untuk lebih jelasnya penjelasan di atas dapat dilihat pada histogram bawah ini: 

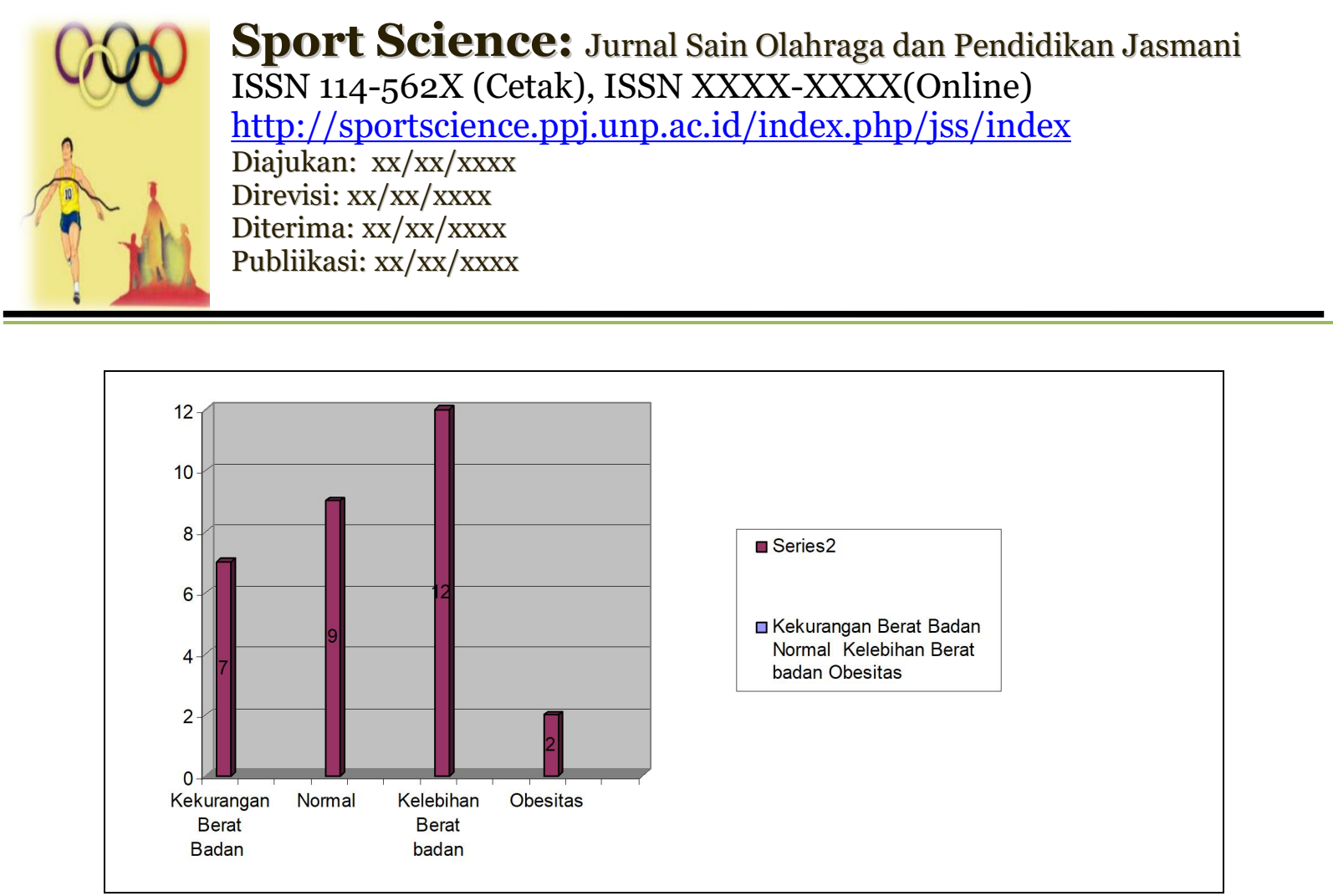

Gambar. 2 histogram berat badan pree test

Dari gambar di atas dapat dilihat 7 orang anggota sanggar senam female aerobic centre padang memiliki berat badan yang kurang, 9 orang anggota sanggar senam female aerobic centre padang memiliki berat badan yang normal, 12 orang anggota sanggar senam female aerobic centre padang memiliki kelebihan berat badan dan 2 orang anggota sanggar senam female aerobic centre padang memiliki berat badan pada level obesitas.

Sementara itu histogram berat badan setelah di lakukanya Latihan Mixed Impact Aerobic dapat dilihat pada gambar berikut ini :

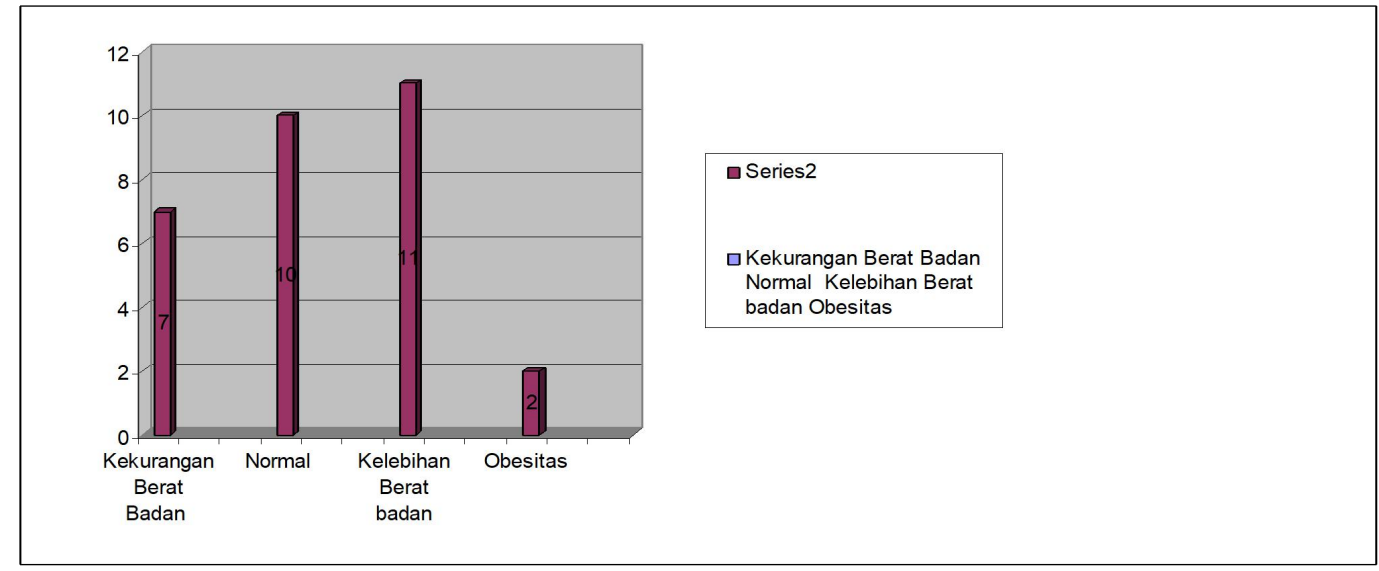

Gambar. 3 histogram berat badan post test

Dari gambar pada halaman sebelumnya dapat dilihat 7 orang anggota sanggar senam female aerobic centre padang memiliki berat badan yang kurang, 10 orang anggota sanggar senam female aerobic centre padang memiliki berat badan yang normal, 11 orang anggota sanggar senam female aerobic centre padang memiliki kelebihan berat badan dan 2 orang anggota sanggar senam female aerobic centre padang memiliki berat badan pada level obesitas.

\section{A. UJI PERSYARATAN ANALISIS}

Hasil uji normalitas dari data berat badan dari tes awal dan tes akhir menggunakan Kolmogorov-Smirnov Test menunjukkan bahwa data tidak berbeda nyata $(p>\alpha 0,05)$ atau $\mathrm{D}^{*}$ 
(Kolmogorov-Smirnov $)_{\mathrm{hit}}<$ Kolmogorov-Smirnov tab. Artinya data berdistribusi normal. Hasil lendkap dapat dilihat Kolmogorov-SmirnovTest dapat dilihat pada tabel berikut:

Tabel IV.

Uji Normalitas Data Penelitian

(Kolmogorov-Smirnov)

\begin{tabular}{|c|c|c|c|c|}
\hline Kelompok & & Tes Awal & $\begin{array}{c}\text { Tes } \\
\text { Akhir }\end{array}$ & Ket \\
\hline Latihan Mixed & N & 30 & 30 & \\
Impact Aerobic & Kolmogorov-Smirnov Z & 0.916 & 0.997 & Normal \\
& Asymp. Sig (2-tailed) & 0.371 & 0.273 & Normal \\
\hline & & & & \\
\hline
\end{tabular}

Tujuan utama dari pengujian reliabilitas adalah untuk mengetahui konsistensi atau keteraturan hasil pengukuran suatu instrumen apabila instrumen tersebut digunakan lagi sebagai alat ukur suatu objek atau responden. Hasil uji reliabilitas mencerminkan dapat dipercaya dan tidaknya suatu instrumen penelitian berdasarkan tingkat kemantapan dan ketepatan suatu alat ukur (Triton PB,2006).

Sedangkan uji validitas atau kesahihan digunakan untuk mengetahui seberapa tepat alat ukur mampu melakukan fungsinya.

\section{a. Uji Reliabilitas}

Untuk mengetahui reliabilitas data pada penelitian ini dapat dilihat pada tabel di bawah ini :

Tabel V. Hasil Uji Reliabilitas dengan SPSS. V.12

Reliability Statistics

\begin{tabular}{|r|r|}
\hline $\begin{array}{c}\text { Cronbach's } \\
\text { Alpha }\end{array}$ & $\begin{array}{c}\text { N of } \\
\text { Items }\end{array}$ \\
\hline .984 & 2 \\
\hline
\end{tabular}

Ini artinya nilai Alpha Cronbach's adalah 0.984 dengan jumlah variabel 2. Nilai $r_{\text {tabel }}$ untuk uji dua sisi pada taraf kepercayaan $95 \%$ atau signifikan $5 \%(\mathrm{p}=0,05)$ dapat dicari berdasarkan jumlah sampel atau $\mathrm{N}$. Oleh karena $\mathrm{N}=30$, maka derajat bebasnya adalah $\mathrm{N}-2=30-2=28$. pada nilai $\mathrm{r}_{\text {tabel }}$ satu sisi pada taraf $\mathrm{df}=10$ dan $\mathrm{p}=0,05$ adalah 0.349 .

Oleh karena nilai Alpha Cronbach's $=0.984$ ternyata lebih besar dari $\mathrm{r}_{\text {tabel }}=0.349$, maka data penelitian ini reliabel.

\section{b. Uji Validitas} berikutnya:

Untuk mengetahui validitas data pada penelitian ini dapat dilihat pada tabel di halaman

Tabel VI. Hasil Uji Validitas dengan SPSS. V.12

Item-Total Statistics

\begin{tabular}{|l|r|r|r|r|}
\hline & $\begin{array}{c}\text { Scale Mean if } \\
\text { Item Deleted }\end{array}$ & $\begin{array}{c}\text { Scale } \\
\text { Variance if } \\
\text { Item Deleted }\end{array}$ & $\begin{array}{c}\text { Corrected } \\
\text { Item-Total } \\
\text { Correlation }\end{array}$ & $\begin{array}{c}\text { Cronbach's } \\
\text { Alpha if Item } \\
\text { Deleted }\end{array}$ \\
\hline Tes_Awal & 55.7833 & 54.374 & .970 & .307 \\
Tes_Akhir & 57.3333 & 61.885 & .970 & .307 \\
\hline
\end{tabular}

Dari tabel di atas semua variabel (Tes Awal dan Tes Akhir) memiliki nilaiCorrected ItemTotal Correlation $>\mathrm{r}_{\text {tabel. }}$. Karena semua nilai Corrected Item-Total Correlation besar dari 0.349, maka dapat dikatakan semua instrumen penelitian valid untuk digunakan. Uji ini bertujuan melihat, apakah dua sampel berpasangan mempunyai rata-rata berbeda atau tidak. Uji ini dilakukan dua sisi (2-tailed) 


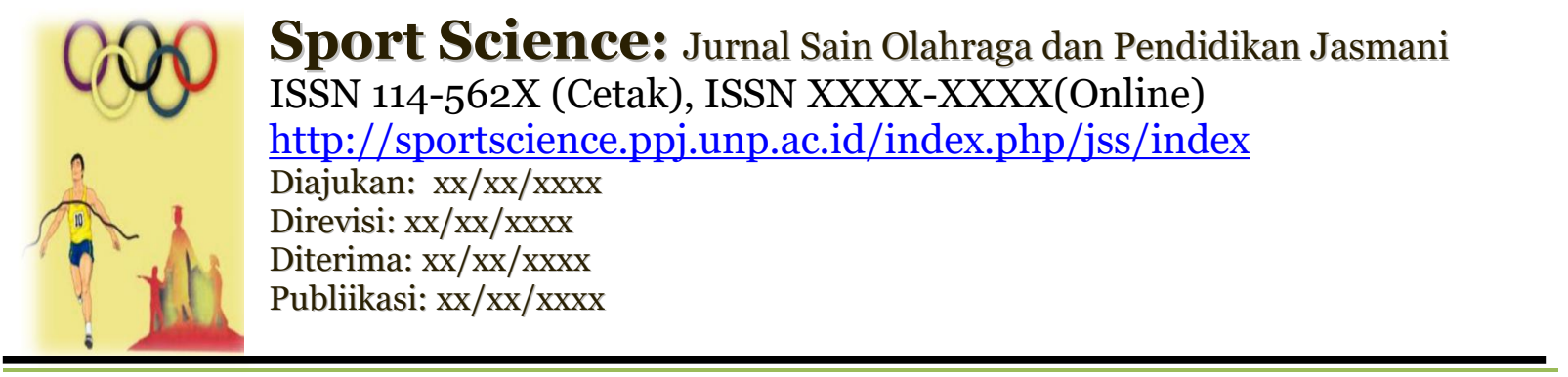

karena akan diketahui rerata kesamaan satu dengan kesamaan dua, sama atau tidak (besar atau lebih kecil).

Sampel berpasangan (pairedsampel) merupakan sebuah sampel dengan subjek yang sama, namun mengalami dua pengukuran yang berbeda. Dalam hal ini hasil analisis menampilkan apakah Latihan Mixed Impact Aerobic berpengaruh terhadap berat badan anggota sanggar senam female aerobic centre padang.

\section{a. Latihan Mixed Impact Aerobic}

Analisis paired sampel test variabel kelompok Latihan Mixed Impact Aerobic, diperoleh nilai probabilitas $p 0.000<\alpha 0,05$, dan $\mathrm{t}_{\text {hit }} 4.39>\mathrm{t}_{\mathrm{tab}}(2.04)$. Ini menyatakan bahwa rerata pengukuran variabel sangat kuat (signifikan) dan terdapatnya peningkatan secara nyata dari perlakuan yang diberikan, untuk lebih jelasnya dapat dilihat pada tabel di halaman berikutnya.

Tabel VII. Paired Sampel Test

Data Kelompok Latihan Mixed Impact Aerobic

\begin{tabular}{|c|c|c|c|c|}
\hline Data penelitian & $\mathrm{t}_{\text {hit }}$ & $\mathrm{t}_{\text {tab }}$ & Df & Sig. $(p)$ \\
\hline $\begin{array}{c}\text { Berat Badan (Data Awal) } \\
-\end{array}$ & 4.39 & 2.04 & 29 & 0.000 \\
Berat Badan (Data Akhir) & & & & \\
\hline
\end{tabular}

Dari pengolahan data yang telah dilakukan dengan menggunakan uji $t$, didapat hasil dari pengujian tersebut dengan skor $t_{\text {hit }} 4.39$, sedangkan $t_{\text {tab }}$ yang dilihat pada daftar uji t pada taraf 0,05 dengan derajat kebebasan $(\mathrm{dk})=\mathrm{n}-1=30-1=29$ adalah 2.04. karena $t_{\mathrm{hit}}>\mathrm{t}_{\mathrm{tab}}$ atau $4.39>2.04$ maka terdapat pengaruh yang berarti antara Latihan Mixed Impact Aerobic terhadap berat badan Anggota Sanggar Senam Female Aerobic Centre Padang.

\section{Pembahasan}

Perhitungan Uji thanya dapat digunakan untuk menguji perbedaan mean dari dua sampel yang diambil dari suatu populasi yang berdistribusi normal, serta data yang diperoleh dalam skala interval atau rasio. Uji t dapat berlaku untuk sampel yang berkorelasi (dependent atau correlated sampel) atau sampel bebas (independent sampel). Untuk kedua jenis sampel tersebut mempunyai formula yang berbeda dalam penggunaannya. Dari perhitungan uji t antara pengaruh Latihan Mixed Impact Aerobic terhadap berat badan diperoleh $t_{\text {hit }} 4.39$ untuk tab pada taraf signifikan $\alpha=0,05$ yaitu 2.04. Berarti dalam hal ini terdapat pengaruh yang berarti antara Latihan Mixed Impact Aerobic terhadap berat badan anggota sanggar senam female aerobic centre padang.

Senam aerobic mixed impact menurut Jonni (2003: 6) merupakan latihan gabungan dari dua jenis senam yaitu senam aerobic low impact dan senam aerobic high impact. Bila kita mengangkat lutut harus betul-betul terangkat, jika tidak dapat menggunakan gerakan lompatan/loncatan. Sumosardjono (1996:63) mengatakan salah satu keuntungan melakukan senam aerobic mixed impact adalah tidak mudah menyebabkan kebosanan karena gerakannya yang bervariasi.

Dari hasil analisis diatas dapat diambil kesimpulan bahwa Latihan Mixed Impact Aerobic dapat membuat perubahan yang berati dari massa tubuh seseorang, apabila Latihan Mixed Impact Aerobic dilakukan dengan benar dan pemberian dosis latihan yang tepat. Penerapan program Latihan Mixed Impact Aerobic yang kurang terencana akan mengakibatkan perubahan berat badan yang ingin dicapai dari anggota sanggar senam female aerobic centre padang tidak akan ada artinya.

Dalam pelaksaaannya Latihan Mixed Impact Aerobic yang diterapkan pada penelitian ini berdurasi 18 kali pertemuan. Diharapkan kepada para peserta senam untuk dapat melakukan Latihan Mixed Impact Aerobic dengan kontiniu atau tidak terputus-putus, untuk mendapat hasil yang sempurna dari proses latihan tersebut. 


\title{
Sport Science: Jurnal Sain Olahraga dan Pendidikan Jasmani
} ISSN 114-562X (Cetak), ISSN XXXX-XXXX(Online) http://sportscience.ppj.unp.ac.id/index.php/jss/index

Program Latihan Mixed Impact Aerobic yang dilakukan untuk membakar lemak tubuh dengan efek terhadap berat badan, dan untuk meningkatkan kebugaran jasmani, didalam melakukan gerakannya lutut harus betul-betul terangkat, jika tidak dapat menggunakan momentum lompatan, diiringi oleh musik, dipimpin oleh instruktur yang berpengalaman, serta lamanya latihan adalah 15-60 menit. Dari hasil penelitian yang telah dilakukan didapat efek yang sangat jelas dari program latihan yang mempengaruhi dari berat badan seseorang.

Dalam penelitian ini peneliti menyadari keterbatasan sebagai manusia, walaupun sudah dicoba untuk mengatasi kemungkinan gangguan terhadap variabel penelitian, tetapi dalam kenyataan sulit untuk menghindari munculnya permasalahan selama penelitian dilakukan antara lain: sulitnya melakukan kontrol secara ketat terhadap sampel, karena sampel tinggal di rumah masing - masing.

Kemudian kelihatan dalam melakukan perlakuan masih ada yang kurang serius, tetapi peneliti berusaha memberi motivasi secara maksimal agar bisa melakukan dengan baik. Dan peneliti juga tidak bisa mengontrol aktivitas di luar dan gizinya.

\section{KESIMPULAN}

Berdasarkan analisis data dan pembahasan, maka dapat dikemukakan kesimpulkan sebagai berikut.Hasil yang diperoleh dari Latihan Mixed Impact Aerobic mempunyai pengaruh yang signifikan dengan berat badan, ini ditandai dengan hasil yang diperoleh yaitu $t_{\text {hit }} 4.39$ untuk $t_{\text {tab }}$ pada taraf signifikan $\alpha=0,05$ derajat kebebasan $(\mathrm{dk})=\mathrm{n}-1=30-1=29=2.04$, ini artinya terdapat pengaruh yang berarti antara Latihan Mixed Impact Aerobic terhadap berat badan Anggota Sanggar Senam Female Aerobic Centre Padang.

Berdasarkan dari hasil penelitian, maka dapat dikemukakan beberapa saran: 1) Untuk dapat menurunkan berat badan dapat dipakai Program Latihan Mixed Impact Aerobic dengan 20 kali pertemuan; 2) Para instruktur senam untuk dapat menerapkan Program Latihan Mixed Impact Aerobic dalam proses penurunan berat badan; 3) Pembaca penelitian ini hanya terbatas pada sampel wanita, untuk itu perlu dilakukan penelitian pada sampel pria; 4) kepada peneliti berikutnya diharapkan dapat menemukan program latihan lain yang berhubungan dengan berat badan.

\section{DAFTAR RUJUKAN}

Arikunto, S. (1998). Metodologi Penelitian Suatu Pendekatan Praktek. Jakarta: Rineka Cipta.

\author{
Asnaldi, A. (2016). HUBUNGAN PENDEKATAN LATIHAN MASSED PRACTICE DAN \\ DISTRIBUTED PRACTICE TERHADAP KETEPATAN PUKULAN LOB PEMAIN \\ BULUTANGKIS. Jurnal Menssana, 1(2), 20-26.
}

Jonni (2003) Senam Aerobik: Fakultas Ilmu Keolahragaan Universitas Negeri Padang

Pitnawati (2004) Buku Ajar Senam Aerobic. Fakultas Ilmu Keolahragaan Universitas Negeri Padang

Sudjana. (1989). Metode Statistika. Bandung: Trasito.

Sumosardjono (1996) Dasar-dasar kepelatihan olahraga. FIK UNP

Suryabrata, S. (2006). Psikologi pendidikan suatu pendekatan baru. Bandung: PT Remaja Rosdakarya.

Syafruddin, (2005). Dasar-Dasar Kepelatihan Olahraga. Padang FIK UNP Padang. 